\title{
Abnormal expression of TRIB3 in colorectal cancer: a novel marker for prognosis
}

\author{
N Miyoshi', H Ishii ${ }^{1,2}, K_{\text {Mimori }}^{2}$, Y Takatsuno², H Kim', H Hirose', M Sekimoto', Y Doki' and M Mori*, I,2 \\ 'Department of Gastroenterological Surgery, Osaka University Graduate School of Medicine, Suita, Yamadaoka 2-2, Osaka 565-087 I, Japan; ${ }^{2}$ Division of \\ Molecular and Surgical Oncology, Department of Molecular and Cellular Biology, Kyushu University, Medical Institute of Bioregulation, Tsurumihara 4546, \\ Beppu, Ohita 874-0838, Japan
}

BACKGROUND: TRIB3 is a human homologue of Drosophila tribbles. Previous studies have shown that TRIB3 controls the cell growth through ubiquitination-dependent degradation of other proteins, whereas its significance in the prognosis of colorectal cancer (CRC) is not yet fully understood.

MATERIALS: This study comprised 202 patients who underwent surgery for CRC, as well as 22 cell lines derived from human gastrointestinal cancer. The correlation of gene expression with clinical parameters in patients was assessed. The biological significance was evaluated by knockdown experiments in seven colorectal cancer cell lines.

RESULTS: A total of 20 cancer cell lines (90.9\%) expressed the TRIB3 gene. The assessment in surgical specimens indicated that the gene expression was significantly higher in the cancerous region than in the marginal non-cancerous region. Patients with high TRIB3 expression were statistically susceptible to a recurrence of the disease, and showed poorer overall survival than those with low expression. The assessment of TRIB3 knockdown in five cell lines showed that small interfering RNA (siRNA) inhibition resulted in a statistically significant reduction in cell growth.

CONCLUSION: These data strongly suggest the usefulness of TRIB3 as a marker for predicting the prognosis of CRC patients, showing a basis for the development of effective treatments for CRC. British Journal of Cancer (2009) I 0 I, I664 - |670. doi:I0.1038/sj.bjc.660536 I www.bjcancer.com (C) 2009 Cancer Research UK

Keywords: TRIB3; prognosis; metastasis; colorectal cancer

In many developed countries, including the United States and Japan, cancer is one of the most prominent illnesses in public welfare and health measures (Jones et al, 2007; Jemal et al, 2008). The incidence of colorectal cancer (CRC) has increased significantly in recent years, in concert with the changing lifestyle (Kohno et al, 2007). The major cause of death in CRC is liver metastases (Yamasaki et al, 2007). Although treatment of CRC has improved recently, it fails in approximately one-third of the patients who need an alternative strategy for coping with death (Jones et al, 2007). In this matter, useful predictive markers would be desired in the medication of CRC patients.

As shown in other tumours, tumour-promoting oncogenes and tumour suppressors control cell proliferation through cell-cycle arrest of CRC (Aliaga et al, 1999; Jemal et al, 2008; Yamatodani et al, 2009). Further identification of genes responsible for the development and progression of CRC, as well as understanding of their clinical significance, would lead to efficient diagnosis and treatment of the disease. Characterization of key molecules is

*Correspondence: Dr M Mori, Department of Gastroenterological Surgery, Osaka University Graduate School of Medicine, Suita, Yamadaoka 2-2, Osaka 565-087I, Japan;

E-mail: mmori@gesurg.med.osaka-u.ac.jp

Received 16 July 2009; revised 9 September 2009; accepted 10 September 2009 particularly promising for the development of new approaches for the treatment of gastrointestinal tumours.

Previous studies have shown that chromosomal aberrations occur during carcinogenesis, and relate to patients' prognoses in CRC (Hermsen et al, 2002; Leslie et al, 2003). Alterations of particular loci at chromosome 20 are reported, indicating the significance of studies on this chromosomal region (Wang et al, 2001; Pledgie et al, 2005; Yde et al, 2007; Goodwin et al, 2008; Shor et al, 2008). It has been shown that aberrant gains at chromosome 20 are specifically associated with mutations in the tumour suppressor gene, TP53, by a survey of 50 cases of CRC, and they are also correlated with the progression of CRC, suggesting that the tumour suppressor pathway is involved in the maintenance of particular chromosomal regions (Wang et al, 2001; Leslie et al, 2003; Pledgie et al, 2005; Yde et al, 2007; Goodwin et al, 2008; Shor et al, 2008).

Although previous studies suggest candidate genes in the regions at chromosome 20 , which might have a role in CRC, it is yet to be fully understood in prognostic value (Wu et al, 2006; Zheng et al, 2008; Antonacopoulou et al, 2008). Here we report on TRIB3 gene in the chromosomal region at 20p13, which is overexpressed in CRC, as a new marker for prognosis and metachronous metastasis. Trib3 is a human homologue of Drosophila tribbles 3, which regulates cell growth, differentiation, oogenesis and metabolism by promoting ubiquitination-dependent degradation of other proteins, interacts with several transcriptional factors and is expressed in several tumours (Mata et al, 2000; Bowers et al, 
2003; Du et al, 2003; Koo et al, 2004; Boudeau et al, 2006; He et al, 2006; Koh et al, 2006; Matsushima et al, 2006; Ord et al, 2007; Kato and Du, 2007; Xu et al, 2007; Yao and Nyomba, 2008). We studied the TRIB3 gene in 202 paired cancerous and non-cancerous regions of CRC, as well as 7 colorectal cancer cell lines and 15 other gastrointestinal cancer cell lines. Our data indicate the clinical significance of TRIB3 in the evaluation of CRC prognosis.

\section{MATERIALS AND METHODS}

\section{Cell lines and culture}

A total of 22 cell lines derived from human CRC and other gastrointestinal cancer (for CRC: Caco2, DLD-1, LoVo, HCT116, HT-29, KM12SM and SW480; for oesophageal cancer: TE-5, TE-8 and TE-10; for gastric cancer: MKN28 and MKN45; for pancreatic cancer: MIAPaCa-2, PANC-1 and PSN-1; for hepatocellular carcinoma: HuH-7, HepG2, Hep3B, HLE, HLF and PLC; for cholangiocellular carcinoma: HuCCT-1) were maintained in Dulbecco's modied Eagle's medium containing $10 \%$ fetal bovine serum and antibiotics at $37^{\circ} \mathrm{C}$ in a $5 \%$ humidified $\mathrm{CO}_{2}$ atmosphere. For small interfering RNA (siRNA) inhibition, double-stranded RNA duplexes targeting human TRIB3 (5'-GCGGUUGGAGUUGG AUGACAACUUA- $3^{\prime}$ and $5^{\prime}$-GCGUGAUCUCAAGCUGUGUCGCU UU- $3^{\prime}$ ) were purchased as a Validated Stealth RNAi kit (Invitrogen, Carlsbad, CA, USA), as well as negative control siRNA (12935-112, Stealth RNAi Negative Control, Medium GC Duplex, Invitrogen). CRC cell lines were transfected with siRNA at a concentration of $20 \mu \mathrm{mol} \mathrm{ml}^{-1}$ using lipofectamine RNAiMAX (Invitrogen), incubated in glucose-free Opti-MEM (Invitrogen) and analysed using CellTac, a proliferation assay kit (Invitrogen). Values are presented as means \pm s.d. from all independent experiments performed in triplicate.

\section{Clinical tissue samples}

The study comprised 202 patients who underwent surgery for CRC, including 118 patients at Kyusyu University from 1992 to 2002, and 84 patients at Osaka University from 2002 to 2006. Primary CRC specimens and adjacent normal colorectal mucosa were obtained from patients after written informed consent had been confirmed, in accordance with institutional ethics guidelines. The surgical specimens were fixed in formalin, processed through graded ethanol and embedded in paraffin, and were sectioned with haematoxylin and eosin staining (see the Supplementary Information). For RNA study, all specimens were frozen immediately after resection in liquid nitrogen and were kept at $-80^{\circ} \mathrm{C}$ until RNA extractions. None of the patients received chemotherapy or radiotherapy before surgery. After surgery, patients were followed up with blood examinations including those for tumour markers, such as serum carcinoembryonic antigen and cancer antigen (CA19-9), and imaging modalities such as abdominal ultrasonography, computed tomography and chest X-ray every 3-6 months. Clinico-pathological factors were assessed according to the criteria of tumour-node-metastasis (TNM) classification of the International Union Against Cancer (UICC) (Sobin and Fleming, 1997).

\section{RNA preparation and reverse transcriptase PCR (RT - PCR)}

Total RNA was prepared using TRIzol reagent (Invitrogen) or with DNase by a modified acid guanidium-phenol-choroform procedure (Mimori et al, 1997). Reverse transcription was performed with SuperScriptII (Invitrogen) or with $2.5 \mu \mathrm{g}$ of total RNA as previously described (Mori et al, 1993). A 158-bp TRIB3 fragment was amplified. Two human TRIB3 oligonucleotide primers for the PCR reaction were designed as follows: $5^{\prime}$-TGCCCTACAGGC ACTGAGTA-3' (forward); 5'-GTCCGAGTGAAAAAGGCGTA-3' (reverse). The forward primer is located in exon 2 and the reverse primer in exon 3. To confirm PCR amplification, 25-35 cycles of PCR reaction were performed using a PCR kit (Takara, Kyoto, Japan) on a Geneamp PCR system 9600 (PE Applied Biosystems, Foster City, CA, USA) with the following parameters: $95^{\circ} \mathrm{C}$ for $10 \mathrm{~s}$, $60^{\circ} \mathrm{C}$ for $10 \mathrm{~s}$ and $72^{\circ} \mathrm{C}$ for $60 \mathrm{~s}$. An $8-\mu \mathrm{l}$ aliquot of each reaction mixture was size-fractionated in a $1.5 \%$ agarose gel and visualised using ethidium bromide staining. To confirm RNA quality, a PCR amplification of $270 \mathrm{bp}$ was performed for the glyceraldehyde-3phosphate dehydrogenase $(G A P D H)$ gene using the following primers: $5^{\prime}$-TTGGTATCGTGGAAGGACTCA-3' and $5^{\prime}$-TGTCAT CATATTGGCAGGTT- $3^{\prime}$. Human reference complementary DNAs were used as positive controls (Clontech).

\section{Quantitative real-time RT - PCR}

For quantitative assessment, quantitative real-time RT-PCR was performed using a kit, LightCycler FastStart DNA Master SYBR Green I (Roche Diagnostics, Tokyo, Japan), for PCR amplification of TRIB3 and GAPDH. The amplification protocol consisted of denaturation at $95^{\circ} \mathrm{C}$ for $10 \mathrm{~s}$, annealing at $60^{\circ} \mathrm{C}$ for $10 \mathrm{~s}$ and elongation at $72^{\circ} \mathrm{C}$ for $10 \mathrm{~s}$. The products were then subjected to a temperature gradient from 55 to $95^{\circ} \mathrm{C}$ with continuous fluorescence monitoring to produce a melting curve of the products. The expression ratios of mRNA copies in tumour and normal tissues were calculated to normalise against GAPDH mRNA expression.

\section{Immunohistochemistry}

A total of 20 cases of CRC surgical specimens from formalin-fixed, paraffin-embedded tissues were used for Trib3 immunohistochemistry. After deparaffinization and blocking, the antigenantibody complex was incubated overnight at $4{ }^{\circ} \mathrm{C}$. ENVISION reagents (Dako Cytomation, Glostrup, Denmark) were used to detect the signal from the antigen - antibody reaction. All sections were counterstained with haematoxylin. The primary anti-Trib3 rabbit polyclonal antibody (HPA015272; Sigma, St Louis, MO, USA) was used at a dilution of $1: 100$. All sections were independently examined for protein expression, and assessed by comparison of staining between normal and cancer regions under microscopic examination of $\geqslant 100$ fields in each specimen.

\section{Proliferation assay}

To determine the proliferative properties, $1.0 \times 10^{5}$ cells were seeded and cultured into each 24 -well dish. The cell growth rate was measured by counting cells using a CellTac kit (Nihon Koden, Tokyo, Japan).

\section{Statistical analysis}

For continuous variables, data are expressed as mean \pm s.d. The relationship between TRIB3 expression and clinico-pathological factors was analysed using $\chi^{2}$ and Student's $t$-tests. Kaplan-Meier survival curves were plotted and compared with the generalised log-rank test. Univariate and multivariate analyses for the identification of prognostic factors were performed using a Cox proportional hazard regression model. All tests were analysed using JMP software (SAS Institute, Cary, NC, USA). Differences with $P$-values $<0.05$ were considered statistically significant.

\section{RESULTS}

\section{Expression of TRIB3 in CRC cell lines and clinical tissue specimens}

We first studied the expression of TRIB3 gene, and evaluated it in gastrointestinal cancer cell lines and clinical tissue samples 


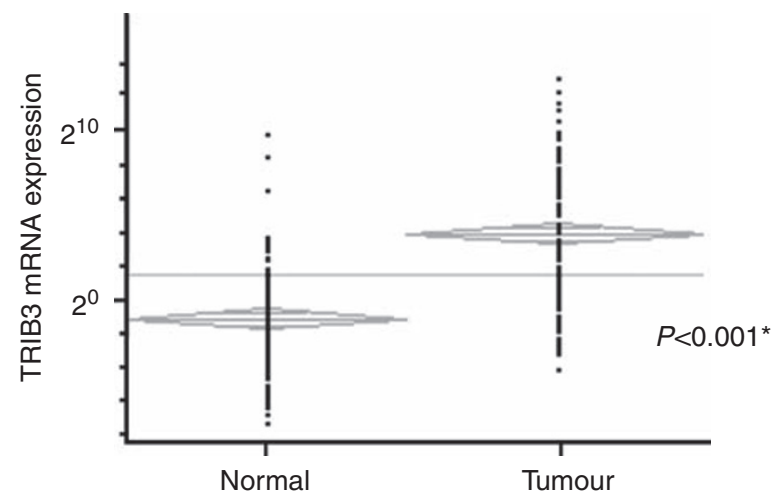

Figure I TRIB3 mRNA expression in clinical tissue specimens Quantitative real-time RT-PCR on 202 paired clinical samples showed that I8I of $202(89.6 \%)$ samples had higher levels of TRIB3 mRNA in tumours than in paired normal regions. The mean expression value of TRIB3 mRNA in tumour regions, 154.62 \pm 1021.63 (mean \pm s.d.; normalised by GAPDH gene expression), was significantly higher than the value, $6.98 \pm 4.91$, for the corresponding normal regions $(P<0.00$ I; Student's $t$-test). GAPDH $=$ glyceraldehydes-3-phosphate dehydrogenase; $\mathrm{RT}-\mathrm{PCR}=$ reverse transcriptase PCR; TRIB3 = tribbles homologue 3.

by RT-PCR analysis to confirm that the PCR amplification was specific and produced a single band in agarose gel, stained with ethidium bromide, before performing real-time PCR. The RT - PCR study of TRIB3 in 22 human gastrointestinal cancer lines indicated 20 cells (90.9\%; TE-8, TE-10, MKN45, MIAPaCa-2, PANC-1, PSN-1, HuH-7, HepG2, Hep3B, HLE, HLF, PLC, HuCCT-1, Caco2, DLD-1, LoVo, HCT116, HT-29, KM12SM and SW480) that expressed the TRIB3 gene with a band in gel (the Supplementary Figure S1A). The RT-PCR analysis of TRIB3 in primary CRC samples was then performed in paired normal and tumour samples (representative data shown in Supplementary Figure S1B: TRIB3 expression was higher in cancerous regions than in normal regions). Quantitative real-time RT-PCR on 202 paired cancer and normal samples showed that 181 of $202(89.6 \%)$ samples had higher levels of TRIB3 mRNA in cancerous regions than in normal regions (Figure 1). The mean expression value of TRIB3 mRNA in cancerous regions (normalised by GAPDH gene expression) was significantly higher than the value in the corresponding normal regions $(P<0.001$; Student's $t$-test).

\section{Expression of Trib3 protein}

Figure 2 shows a representative immunohistochemical staining pattern for Trib3 in tissue from a CRC patient. Trib3 protein staining was observed in the nucleus and cytoplasm in epithelial cells; the expression of CRC was compared with non-cancerous epithelial cells, whereas the expression was appreciably weak or hardly detectable in stromal cells. Examination of 20 cases, which were selected randomly, indicated that 16 cases showed a higher expression level of Trib3 protein in cancerous regions compared with normal regions, whereas the remaining four cases showed no difference between normal and cancerous regions. To compare the data, mRNA expression was assessed by gel RT - PCR and real-time $\mathrm{RT}-\mathrm{PCR}$. The data show that mRNA expression was high level in all 16 immunohistochemistry-positive tumours, whereas mRNA expression was comparable in normal and cancerous regions of the remaining four tumours, suggesting that the high expression of Trib3 protein is associated with mRNA expression $(P<0.001$; $\chi^{2}$ test). No variation of staining intensity for Trib3 was observed in each of the specimens. We concluded that both mRNA and the protein coded by this gene are associated and frequently expressed together in CRC.

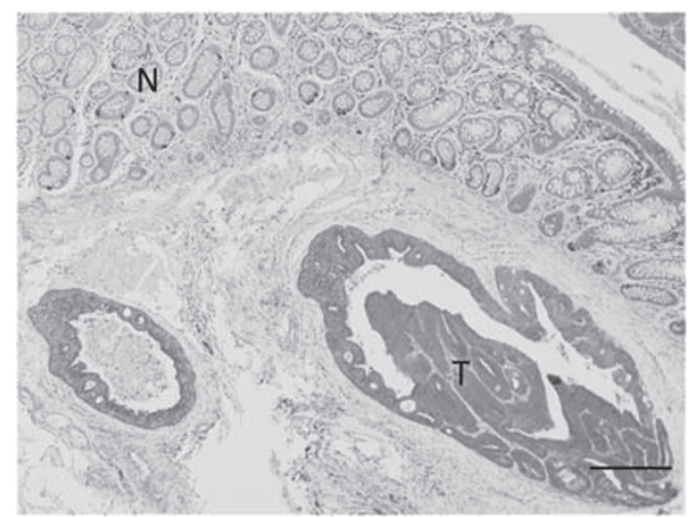

Figure 2 Immunohistochemical staining for Trib3 in tumour and normal specimens. A representative positive stain for Trib3 in tissues from CRC patients. Positive staining is observed in the nucleus and cytoplasm of cancer cells, but not in stromal cells. Trib3 expression was associated with mRNA expression. $C R C=$ colorectal cancer; $T=$ tumour cells; $\mathrm{N}=$ normal glandular cells. Bar $=200 \mu \mathrm{m}$ (original magnification, $\times 20$ ).

Table I Clinicopahological factors and TRIB3 mRNA expression in 202 colorectal cancers

\begin{tabular}{|c|c|c|c|}
\hline Factors & $\begin{array}{c}\text { High expression } \\
\text { (\%) }\end{array}$ & $\begin{array}{c}\text { Low expression } \\
\text { (\%) }\end{array}$ & $P$-value \\
\hline \multicolumn{4}{|l|}{ Age (years) } \\
\hline$\leqslant 67$ & $45(44.5)$ & $51(50.5)$ & \multirow[t]{2}{*}{0.397} \\
\hline $67<$ & $56(55.5)$ & $50(49.5)$ & \\
\hline \multicolumn{4}{|l|}{ Gender } \\
\hline Male & $63(62.4)$ & $52(5 \mid .5)$ & \multirow[t]{2}{*}{0.118} \\
\hline Female & $38(37.6)$ & $49(48.5)$ & \\
\hline \multicolumn{4}{|c|}{ Histological grade } \\
\hline Wel-Mod & $95(94.1)$ & $89(88.1)$ & \multirow[t]{2}{*}{0.138} \\
\hline Others & $6(5.9)$ & $12(11.9)$ & \\
\hline \multicolumn{4}{|c|}{ Tumour size (mm) } \\
\hline$\leqslant 30$ & $24(23.8)$ & $22(21.8)$ & \multirow[t]{2}{*}{0.737} \\
\hline $30<$ & 77 (76.2) & 79 (78.2) & \\
\hline \multicolumn{4}{|c|}{ Tumour invasion } \\
\hline Tis & $5(5.0)$ & $10(9.9)$ & \multirow[t]{5}{*}{0.418} \\
\hline TI & $6(5.9)$ & II (I0.9) & \\
\hline T2 & $20(19.8)$ & $19(18.8)$ & \\
\hline T3 & $49(48.5)$ & $44(43.6)$ & \\
\hline T4 & $21(20.8)$ & $17(16.8)$ & \\
\hline \multicolumn{4}{|c|}{ Lymph node metastasis } \\
\hline No & $60(59.4)$ & $61(60.4)$ & \multirow[t]{2}{*}{0.885} \\
\hline $\mathrm{NI}-2$ & $4 I(40.6)$ & $40(36.6)$ & \\
\hline \multicolumn{4}{|c|}{ Lymphatic invasion } \\
\hline Absent & $49(48.5)$ & $51(50.5)$ & \multirow[t]{2}{*}{0.778} \\
\hline Present & $52(5 \mid .5)$ & $50(49.5)$ & \\
\hline \multicolumn{4}{|c|}{ Venous invasion } \\
\hline Absent & $78(77.2)$ & $74(73.3)$ & \multirow[t]{2}{*}{0.514} \\
\hline Present & $23(22.8)$ & $27(26.7)$ & \\
\hline \multicolumn{4}{|l|}{ Metastasis } \\
\hline MO & $68(67.3)$ & $90(89.1)$ & \multirow[t]{2}{*}{$<0.001$} \\
\hline $\mathrm{MI}$ & $33(32.7)$ & $12(10.9)$ & \\
\hline
\end{tabular}

Wel = well differentiated adenocarcinoma; Mod = moderately differentiated adenocarcinoma; Others = poorly differentiated adenocaricinoma and mucinous carcinoma; TRIB3 tribbles homologue 3. The statistic significance is shown with under line. 


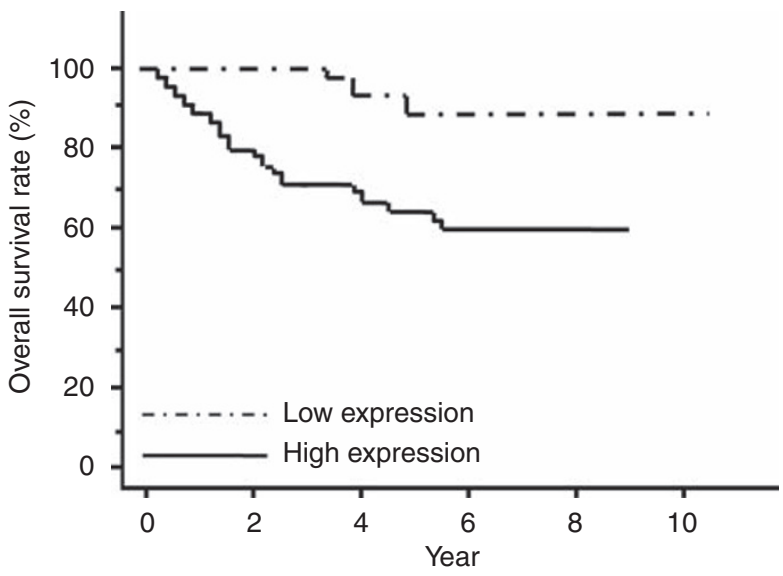

Figure 3 Overall survival rates of patients with $C R C$ on the basis of TRIB3 mRNA expression status. The overall survival rate was significantly lower in the TRIB3 high-expression group than that in the lowexpression group $(P<0.00 \mathrm{I})$. $\mathrm{CRC}=$ colorectal cancer; $\mathrm{TRIB} 3=$ tribbles homologue 3 .

Table 2 Univariate and multivariate analysis for overall survival (Cox proportional hazards regression model)

\begin{tabular}{|c|c|c|c|c|c|c|}
\hline \multirow[b]{2}{*}{ Factors } & \multicolumn{2}{|c|}{$\begin{array}{c}\text { Univariate } \\
\text { analysis }\end{array}$} & \multirow[b]{2}{*}{$P$-value } & \multicolumn{2}{|c|}{$\begin{array}{c}\text { Multivariate } \\
\text { analysis }\end{array}$} & \multirow[b]{2}{*}{$P$-value } \\
\hline & $\mathbf{R R}$ & $95 \% \mathrm{Cl}$ & & $\mathbf{R R}$ & $95 \% \mathrm{Cl}$ & \\
\hline $\begin{array}{l}\text { Age(years) } \\
(\leqslant 67 / 67<)\end{array}$ & 1.23 & $0.85-1.80$ & 0.258 & & & \\
\hline $\begin{array}{l}\text { Gender } \\
\text { (Male / female) }\end{array}$ & 1.93 & $0.90-4.47$ & 0.090 & & & \\
\hline $\begin{array}{l}\text { Histological grade } \\
\text { (Wel-Mod / others) }\end{array}$ & 1.54 & $0.36-4.35$ & 0.511 & & & \\
\hline $\begin{array}{l}\text { Tumour size } \\
(30<1 \leqslant 30)\end{array}$ & 3.70 & $1.69-15.66$ & $\underline{0.001}$ & 2.04 & $0.88-8.79$ & 0.103 \\
\hline $\begin{array}{l}\text { Tumour invasion } \\
\text { (T3-4 / Tis-2) }\end{array}$ & 11.00 & $3.28-68.37$ & $\leq 0.001$ & 2.47 & $0.60-16.82$ & 0.223 \\
\hline $\begin{array}{l}\text { Lymph node metastasis } \\
(\mathrm{NI}-2 \text { / N0) }\end{array}$ & 4.28 & $2.02-9.63$ & $\underline{0.001}$ & 1.49 & $0.65-3.74$ & 0.348 \\
\hline $\begin{array}{l}\text { Lymphatic invasion } \\
\text { (Present / absent) }\end{array}$ & 2.44 & I.14-5.44 & $\underline{0.021}$ & 1.43 & $0.62-3.49$ & 0.396 \\
\hline $\begin{array}{l}\text { Venous invasion } \\
\text { (Present / absent) }\end{array}$ & 2.17 & $0.92-4.73$ & 0.071 & & & \\
\hline $\begin{array}{l}\text { Metastasis } \\
(\mathrm{MI} / \mathrm{MO})\end{array}$ & 21.89 & $9.33-60.11$ & $\leq 0.001$ & 9.34 & $3.70-27.28$ & $\leq 0.001$ \\
\hline $\begin{array}{l}\text { TRIB3 mRNA expression } \\
\text { (median }</<\text { median) }\end{array}$ & 8.45 & $2.97-35.48$ & $<0.001$ & 3.78 & $1.27-16.35$ & $\underline{0.014}$ \\
\hline
\end{tabular}

$\mathrm{RR}=$ relative risk; $\mathrm{Cl}=$ confidence interval; $\mathrm{Wel}=$ well differentiated adenocarcinoma; Mod = moderately differentiated adenocarcinoma; Others = poorly differentiated adenocaricinoma and mucinous carcinoma; TRIB3 tribbles homologue 3. The statistic significance is shown with under lines.

\section{TRIB3 expression and clinico-pathological characteristics}

To study the TRIB3 expression in CRC quantitatively, the data were classified into two experimental groups on the basis of the

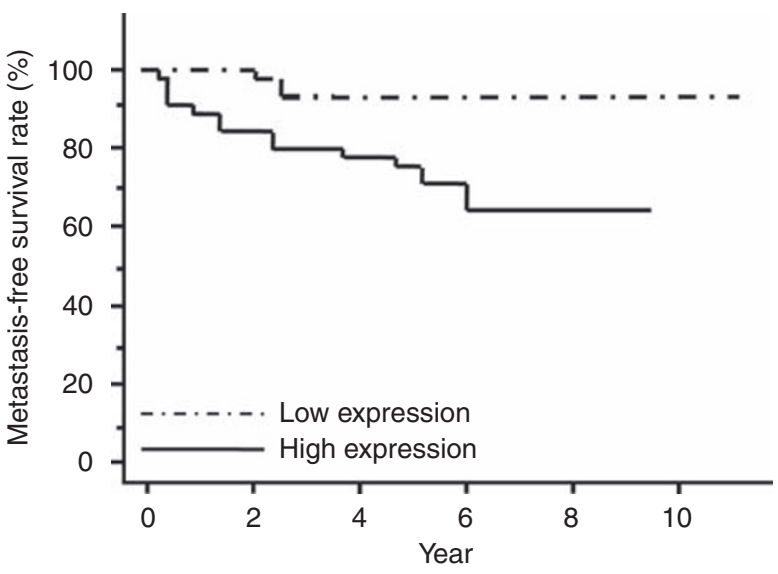

Figure 4 Metachronous metastasis-free over 5 years' survival rates of patients with CRC in stages I II, and III, on the basis of TRIB3 mRNA expression status. The metachronous metastasis-free over 5 years' survival rate was significantly lower in patients with the TRIB3 high-expression group compared with the low-expression group $(P=0.007)$. $C R C=$ colorectal cancer; TRIB3 $=$ tribbles homologue 3.

Table 3 Univariate and multivariate analysis for metachronous metastasis-free over 5 years survival rate (Cox proportional hazards regression model)

\begin{tabular}{|c|c|c|c|c|c|c|}
\hline \multirow[b]{2}{*}{ Factors } & \multicolumn{2}{|c|}{$\begin{array}{l}\text { Univariate } \\
\text { analysis }\end{array}$} & \multirow[b]{2}{*}{$P$-value } & \multicolumn{2}{|c|}{$\begin{array}{l}\text { Multivariate } \\
\text { analysis }\end{array}$} & \multirow[b]{2}{*}{$P$-value } \\
\hline & $\mathbf{R R}$ & $95 \% \mathrm{Cl}$ & & $\mathbf{R R}$ & $95 \% \mathrm{Cl}$ & \\
\hline $\begin{array}{l}\text { Age(years) } \\
(67<1 \leqslant 67)\end{array}$ & 1.33 & $0.85-2.09$ & 0.202 & & & \\
\hline $\begin{array}{l}\text { Gender } \\
\text { (Male / female) }\end{array}$ & 2.44 & $0.97-6.90$ & 0.055 & & & \\
\hline $\begin{array}{l}\text { Histological grade } \\
\text { (Wel-Mod / others) }\end{array}$ & 24.0 & $4.78-101.61$ & $\leq 0.001$ & 25.9 & $3.57-215.84$ & $\underline{0.001}$ \\
\hline $\begin{array}{l}\text { Tumor size } \\
(30<1 \leqslant 30)\end{array}$ & 3.66 & $1.66-15.55$ & $\leq 0.001$ & 3.04 & $1.18-13.62$ & $\underline{0.017}$ \\
\hline $\begin{array}{l}\text { Tumor invasion } \\
\text { (T3-4 / Tis-2) }\end{array}$ & 4.80 & $1.61-20.58$ & $\underline{0.003}$ & 2.77 & $0.67-15.00$ & 0.160 \\
\hline $\begin{array}{l}\text { Lymph node } \\
\text { metastasis } \\
(\mathrm{NI}-2 \text { / No) }\end{array}$ & 4.01 & $1.65-10.26$ & 0.002 & 2.65 & $0.98-7.59$ & 0.054 \\
\hline $\begin{array}{l}\text { Lymphatic invasion } \\
\text { (Present / absent) }\end{array}$ & 4.49 & $1.73-13.83$ & $\underline{0.001}$ & 0.72 & $0.20-2.95$ & 0.637 \\
\hline $\begin{array}{l}\text { Venous invasion } \\
\text { (Present / absent) }\end{array}$ & 3.10 & $1.21-7.53$ & $\underline{0.019}$ & 1.68 & $0.61-4.53$ & 0.301 \\
\hline $\begin{array}{l}\text { TRIB3 mRNA } \\
\text { expression } \\
\text { (median }</ \\
\leqslant \text { median) }\end{array}$ & 4.33 & $1.45-18.59$ & $\underline{0.006}$ & 3.86 & $1.09-19.00$ & $\underline{0.035}$ \\
\hline
\end{tabular}

$\mathrm{RR}=$ relative risk; $\mathrm{Cl}=$ confidence interval; $\mathrm{Wel}=$ well differentiated adenocarcinoma; Mod = moderately differentiated adenocarcinoma; Others = poorly differentiated adenocaricinoma and mucinous carcinoma; TRIB3 tribbles homologue 3. The statistic significance is shown with under lines.

TRIB3 expression levels to assess the expression value without any bias. The high-expression group comprised patients who had a level of TRIB3 expression higher than the median value for TRIB3/ $G A P D H$ expression in tumour regions compared with normal 
regions $(n=101)$; other patients were assigned to the lowexpression group $(n=101)$. Clinico-pathological factors related to TRIB3 expression status are shown in Table 1. Data indicated that metastasis (M0 / M1) was correlated with TRIB3 expression $(P<0.001)$. The metastatic sites were the liver (37 cases), lung (10 cases), brain ( 3 cases) and bone ( 1 case). Metastatic sites and other factors were not significantly correlated with TRIB3 expression.

\section{Relationship between TRIB3 expression and prognosis}

The study of prognosis revealed that the overall survival rate was significantly lower for patients in the high-expression group $(P<0.001$; Figure 3$)$. The median follow-up was 2.98 years. Table 2 shows the univariate and multivariate analyses of factors related to patient prognosis. Univariate analysis showed that the post-operative overall survival was significantly correlated with following factors: tumour size $(P=0.001)$, tumour invasion $(P<0.001)$, lymph node metastasis $(P=0.001)$, lymphatic invasion $(P=0.021)$, metastasis $(P<0.001)$ and TRIB3 expression $(P<0.001)$. Multivariate regression analysis indicated that an inclusion in the TRIB3 high-expression group (relative risk $(\mathrm{RR})=3.78 ; 95 \%$ confidence interval $(\mathrm{CI})=1.27-16.35 ; P=0.014)$ was an independent predictor of overall survival, as was metastasis (M1 / M0) $(\mathrm{RR}=9.34 ; 95 \% \mathrm{CI}=3.70-27.28 ; P<0.001)$, indicating a significant link between TRIB3 expression and patient prognosis.

In 65 of 202 patients, we have followed up over 5 years after the primary operation, the median follow-up was 6.31 years. We then evaluated the metachronous, metastasis-free, over 5years' survival in these patients, indicating that the rate was significantly lower in patients of the high-expression group $(P=0.007$, Figure 4$)$. Table 3 shows the univariate and multivariate analyses of factors related to patient prognosis. Univariate analysis showed that the post-operative metastasis was significantly correlated with following factors: histological grade $(P<0.001)$, tumour size $(P<0.001)$, tumour invasion $(P=0.003)$, lymph node metastasis $(P=0.001)$, lymphatic invasion $(P=0.001)$, venous invasion $(P=0.019)$ and TRIB3 mRNA expression $(P=0.006)$. Multivariate regression analysis indicated that inclusion in the TRIB3 high-expression group $(\mathrm{RR}=3.86 ; 95 \% \mathrm{CI}=1.09-19.00$; $P=0.035)$ was an independent predictor of metastasis-free survival, as were histological grade $(\mathrm{RR}=25.9 ; 95 \% \mathrm{CI}=$ $3.57-215.84 ; P=0.001)$ and tumour size $(\mathrm{RR}=3.04 ; 95 \% \mathrm{CI}=$ $1.18-13.62 ; P=0.017)$.

\section{Effect of TRIB3 inhibition in CRC cell growth}

A total of 7 CRC cell lines were subjected to siRNA knockdown. The biological role of TRIB3 in vitro was analysed in CRC, in which TRIB3 expression was knocked down. In the CRC cell lines examined, significant suppression of endogenous TRIB3 expression by siRNA was confirmed by real-time RT-PCR in five cell lines (DLD-1, LoVo, HCT116, KM12SM and SW480; $P<0.05$, Student's $t$-test; Supplementary Figure S2). To determine the proliferative properties, cells were seeded and cultured (Figure 5). There were significant differences in numbers between wild-type or negative control and TRIB3 siRNA $(P<0.05)$ in all five CRC cell lines. There was no significant change in number between negative control and wild type.
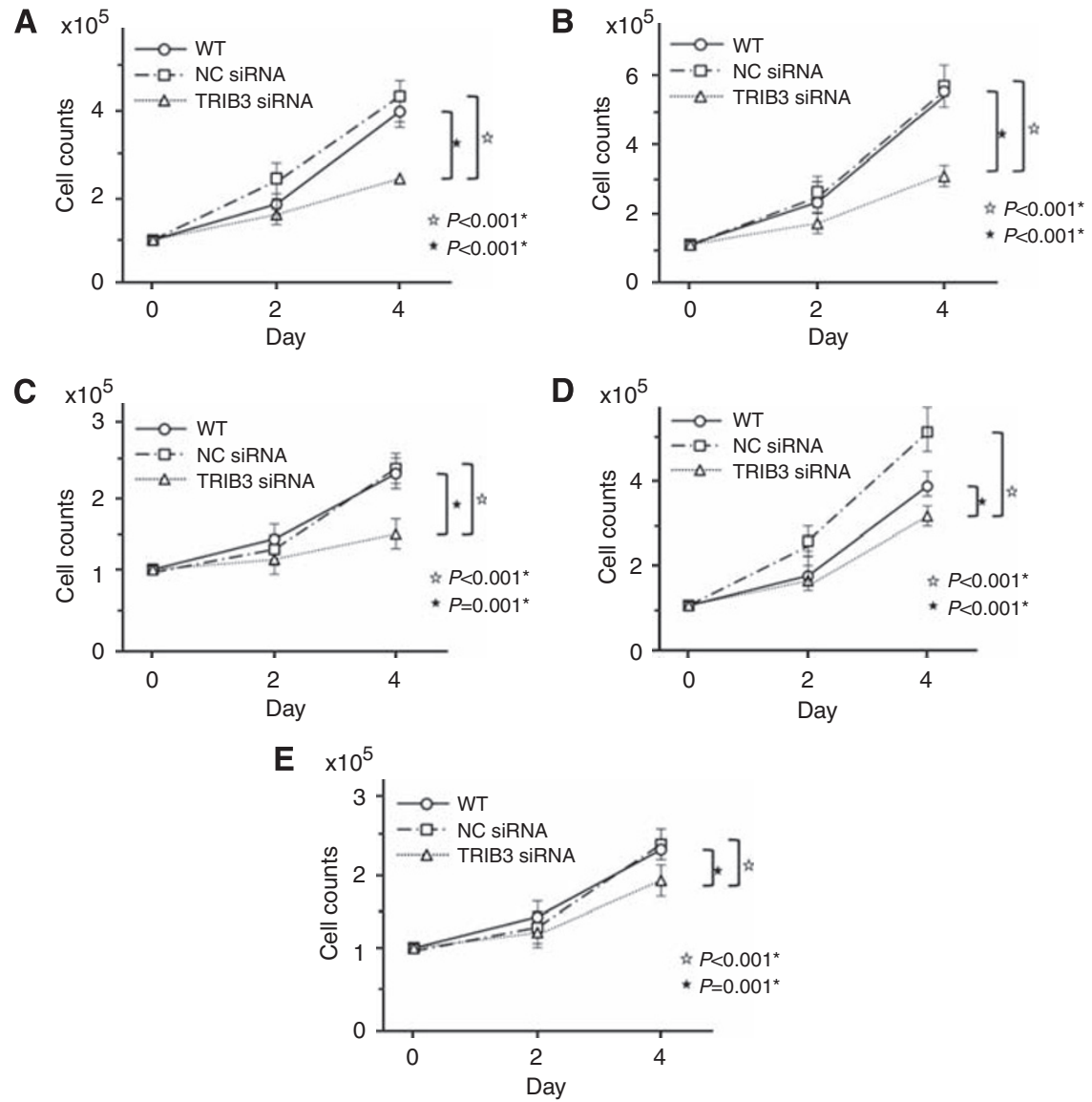

Figure 5 Proliferation assay with siRNA inhibition in five CRC cell lines. Proliferation assay was performed in five CRC cell lines (A, DLD-I; B, LoVo; C, HCT-I I6; D, KMI2SM; E, SW480). There were significant differences between WT or NC, and TRIB3 siRNA. Values are presented means \pm s.d. of three independent experiments. $\mathrm{CRC}=$ colorectal cancer; $\mathrm{NC}=$ negative control; TRIB3 = tribbles homologue 3; WT = wild type. 


\section{DISCUSSION}

This study showed that TRIB3 is expressed at higher levels in CRC than in the corresponding normal regions, and is expressed in gastrointestinal cancer cell lines. The siRNA inhibition experiment showed the functional relevance of expressed TRIB3 in gastrointestinal cancer cell lines. To the best of our knowledge, this study is the first to show the candidacy of TRIB3 as a prognostic CRC marker, supported by the functional relevance to cell growth.

Nowadays, it can be useful to determine the necessity of intensive follow-up and adjuvant therapy for CRC by predicting recurrence and metastases in curative surgical resection (Bathe et al, 2004; Kornmann et al, 2008; Wolpin and Mayer, 2008). In this study, clinico-pathological analysis revealed that TRIB3 is closely related to metastasis, but not to lymphatic metastasis. It may correlate with some mechanism of little concern to invasiveness. Patients with CRCs with high TRIB3 expression showed a poorer prognosis for disease-free and overall survival than those in the low-expression group. Data indicate that TRIB3 is an independent prognostic factor, as well as a very important predictor that is already known (Derkinderen et al, 1990). TRIB3 is presumably a good predictor of metachronous metastasis that can be followed by curative surgical intervention. In gastrointestinal cancer therapy, it is essential to prevent metachronous metastasis. Several adjuvant chemotherapies are helpful in certain disease stages, especially in CRC (Bathe et al, 2004; Andre et al, 2007). Recently, increasing evidence has been accumulated, showing the usefulness of less invasive surgery in the treatment of CRC, such as laparoscopic and endoscopic surgery (Lacy et al, 2002; Weeks et al, 2002; Clinical Outcomes of Surgical Therapy Study Group, 2004; Jayne et al, 2007). For these cases, predictive markers of tumour invasion and metastasis, which are independent of traditional TNM classification and contribute collectively to diagnoses and treatments, are very important. These data indicate the candidacy of TRIB3.

Although improving treatments such as pre-operative and post-operative chemotherapy and radiotherapy combined with surgery for CRC have contributed to the reduction of recurrences and metastases, half of the cases eventually metastasise despite systemic chemotherapy followed by surgery (Koshariya et al, 2007). Adjuvant chemotherapy for CRC has been desirable in

\section{REFERENCES}

Aliaga JC, Deschenes C, Beaulieu JF, Calvo EL, Rivard N (1999) Requirement of the MAP kinase cascade for cell cycle progression and differentiation of human intestinal cells. Am J Physiol 277: G631 - G641

Andre T, Quinaux E, Louvet C, Colin P, Gamelin E, Bouche O, Achille E, Piedbois P, Tubiana-Mathieu N, Boutan-Laroze A, Flesch M, Lledo G, Raoul Y, Debrix I, Buyse M, de Gramont A (2007) Phase III study comparing a semimonthly with a monthly regimen of fluorouracil and leucovorin as adjuvant treatment for stage II and III colon cancer patients: final results of GERCOR C96.1. J Clin Oncol 25: $3732-3738$

Antonacopoulou AG, Grivas PD, Skarlas L, Kalofonos M, Scopa CD, Kalofonos HP (2008) POLR2F, ATP6V0A1 and PRNP expression in colorectal cancer: new molecules with prognostic significance? Anticancer Res 28: 1221 - 1227

Bathe OF, Dowden S, Sutherland F, Dixon E, Butts C, Bigam D, Walley B, Ruether D, Ernst S (2004) Phase II study of neoadjuvant 5-FU + leucovorin + CPT-11 in patients with resectable liver metastases from colorectal adenocarcinoma. BMC Cancer 4: 32

Boudeau J, Miranda-Saavedra D, Barton GJ, Alessi DR (2006) Emerging roles of pseudokinases. Trends Cell Biol 16: 443-452

Bowers AJ, Scully S, Boylan JF (2003) SKIP3, a novel Drosophila tribbles ortholog, is overexpressed in human tumors and is regulated by hypoxia. Oncogene 22: 2823-2835

Derkinderen DJ, Boxma OJ, Koten JW, Den Otter W (1990) Stochastic theory of oncogenesis. Anticancer Res 10: 497-504 highly suspicious metastatic cases. In these cases, the assessment of TRIB3 expression may be useful to predict patient prognosis.

In biological assessment, this study showed that TRIB3 expression was related to tumour growth in several gastrointestinal cancer cell lines. The in vivo study showed that siRNA inhibition of TRIB3 resulted in a reduction in cell growth of seven gastrointestinal cancer cell lines, significantly $(P<0.05)$. Although previous reports showed that TRIB3 is expressed in several cancer cell lines, this study shows that TRIB3 seems to stimulate proliferation, and may be a new target for the therapy of gastrointestinal cancer (Bowers et al, 2003; Xu et al, 2007).

Tribs, belong to the pseudokinase family consisting of three mammalian isoforms, Trib1, Trib2 and Trib3, have no detectable kinase catalytic activity because of variations in key amino acids in the ATP-binding domain, but possess substrate-binding domains relating to their function as protein-interacting modules (Seher and Leptin, 2000; Yamatodani et al, 2009). Tribs associate with large proteins such as transcriptional factors, and regulate cell growth, differentiation and metabolism (Boudeau et al, 2006).

Trib1 interacts with Mapk and modulates Mapkk activity associated with smooth muscle cell proliferation and migration (Kiss-Toth et al, 2004; Sung et al, 2007). Trib2 has a role in adipogenesis in combination with the degradation of C/EBPbeta (Naiki et al, 2007). Trib3 promotes ubiquitination and degradation of proteins involved in cell-cycle regulation and oogenesis through an interaction with activation transcription factor 4 , and is involved in the Pten pathway through interaction with Akt (Mata et al, 2000; Du et al, 2003; He et al, 2006; Koh et al, 2006; Kato and Du, 2007; Yao and Nyomba, 2008). Trib3 expression is increased in several primary tumours and cancer cell lines and can be controlled by nutrient starvation, which is consistent with these data (Bowers et al, 2003; Schwarzer et al, 2006; Xu et al, 2007). Our report indicates that TRIB3 is not only a new independent prognostic factor and predictor of metachronous metastasis, but is also a useful target because the inhibition of TRIB3 may lead to the reduction of CRC through the control of cell growth.

Supplementary Information accompanies the paper on British Journal of Cancer website (http://www.nature.com/bjc)
Du K, Herzig S, Kulkarni RN, Montminy M (2003) TRB3: a tribbles homolog that inhibits Akt/PKB activation by insulin in liver. Science 300: $1574-1577$

Goodwin AC, Jadallah S, Toubaji A, Lecksell K, Hicks JL, Kowalski J, Bova GS, De Marzo AM, Netto GJ, Casero Jr RA (2008) Increased spermine oxidase expression in human prostate cancer and prostatic intraepithelial neoplasia tissues. Prostate 68: 766-772

Group COoSTS (2004) A comparison of laparoscopically assisted and open colectomy for colon cancer. $N$ Engl J Med 350: 2050-2059

He L, Simmen FA, Mehendale HM, Ronis MJ, Badger TM (2006) Chronic ethanol intake impairs insulin signaling in rats by disrupting Akt association with the cell membrane. Role of TRB3 in inhibition of Akt/ protein kinase B activation. J Biol Chem 281: 11126-11134

Hermsen M, Postma C, Baak J, Weiss M, Rapallo A, Sciutto A, Roemen G, Arends JW, Williams R, Giaretti W, De Goeij A, Meijer G (2002) Colorectal adenoma to carcinoma progression follows multiple pathways of chromosomal instability. Gastroenterology 123: 1109-1119

Jayne DG, Guillou PJ, Thorpe H, Quirke P, Copeland J, Smith AM, Heath RM, Brown JM (2007) Randomized trial of laparoscopic-assisted resection of colorectal carcinoma: 3-year results of the UK MRC CLASICC Trial Group. J Clin Oncol 25: 3061-3068

Jemal A, Siegel R, Ward E, Hao Y, Xu J, Murray T, Thun MJ (2008) Cancer statistics, 2008. CA Cancer J Clin 58: 71-96

Jones OM, John SK, Horseman N, Lawrance RJ, Fozard JB (2007) Cause and place of death in patients dying with colorectal cancer. Colorectal Dis 9: $253-257$ 
Kato S, Du K (2007) TRB3 modulates C2C12 differentiation by interfering with Akt activation. Biochem Biophys Res Commun 353: 933-938

Kiss-Toth E, Bagstaff SM, Sung HY, Jozsa V, Dempsey C, Caunt JC, Oxley KM, Wyllie DH, Polgar T, Harte M, O'Neill L A, Qwarnstrom EE, Dower SK (2004) Human tribbles, a protein family controlling mitogenactivated protein kinase cascades. J Biol Chem 279: 42703-42708

Koh HJ, Arnolds DE, Fujii N, Tran TT, Rogers MJ, Jessen N, Li Y, Liew CW, Ho RC, Hirshman MF, Kulkarni RN, Kahn CR, Goodyear LJ (2006) Skeletal muscle-selective knockout of LKB1 increases insulin sensitivity, improves glucose homeostasis, and decreases TRB3. Mol Cell Biol 26: $8217-8227$

Kohno SI, Luo C, Nawa A, Fujimoto Y, Watanabe D, Goshima F, Tsurumi T, Nishiyama Y (2007) Oncolytic virotherapy with an HSV amplicon vector expressing granulocyte-macrophage colony-stimulating factor using the replication-competent HSV type 1 mutant HF10 as a helper virus. Cancer Gene Ther 14: 918 -926

Koo SH, Satoh H, Herzig S, Lee CH, Hedrick S, Kulkarni R, Evans RM, Olefsky J, Montminy M (2004) PGC-1 promotes insulin resistance in liver through PPAR-alpha-dependent induction of TRB-3. Nat Med 10: $530-534$

Kornmann M, Formentini A, Ette C, Henne-Bruns D, Kron M, Sander S, Baumann W, Kreuser ED, Staib L, Link KH (2008) Prognostic factors influencing the survival of patients with colon cancer receiving adjuvant 5-FU treatment. Eur J Surg Oncol 34: 1316-1321

Koshariya M, Jagad RB, Kawamoto J, Papastratis P, Kefalourous H, Porfiris T, Tzouma C, Lygidakis NJ (2007) An update and our experience with metastatic liver disease. Hepatogastroenterology 54: 2232 - 2239

Lacy AM, Garcia-Valdecasas JC, Delgado S, Castells A, Taura P, Pique JM, Visa J (2002) Laparoscopy-assisted colectomy vs open colectomy for treatment of non-metastatic colon cancer: a randomised trial. Lancet 359: $2224-2229$

Leslie A, Pratt NR, Gillespie K, Sales M, Kernohan NM, Smith G, Wolf CR, Carey FA, Steele RJ (2003) Mutations of APC, K-ras, and p53 are associated with specific chromosomal aberrations in colorectal adenocarcinomas. Cancer Res 63: 4656-4661

Mata J, Curado S, Ephrussi A, Rorth P (2000) Tribbles coordinates mitosis and morphogenesis in Drosophila by regulating string/CDC25 proteolysis. Cell 101: $511-522$

Matsushima R, Harada N, Webster NJ, Tsutsumi YM, Nakaya Y (2006) Effect of TRB3 on insulin and nutrient-stimulated hepatic p70 S6 kinase activity. J Biol Chem 281: 29719-29729

Mimori K, Mori M, Shiraishi T, Fujie T, Baba K, Haraguchi M, Abe R, Ueo H, Akiyoshi T (1997) Clinical significance of tissue inhibitor of metalloproteinase expression in gastric carcinoma. Br J Cancer 76: $531-536$

Mori M, Staniunas RJ, Barnard GF, Jessup JM, Steele Jr GD, Chen LB (1993) The significance of carbonic anhydrase expression in human colorectal cancer. Gastroenterology 105: 820-826

Naiki T, Saijou E, Miyaoka Y, Sekine K, Miyajima A (2007) TRB2, a mouse Tribbles ortholog, suppresses adipocyte differentiation by inhibiting AKT and C/EBPbeta. J Biol Chem 282: 24075-24082

Ord D, Meerits K, Ord T (2007) TRB3 protects cells against the growth inhibitory and cytotoxic effect of ATF4. Exp Cell Res 313: 3556-3567

Pledgie A, Huang Y, Hacker A, Zhang Z, Woster PM, Davidson NE, Casero Jr RA (2005) Spermine oxidase SMO(PAOh1), Not N1-acetylpolyamine oxidase $\mathrm{PAO}$, is the primary source of cytotoxic $\mathrm{H} 2 \mathrm{O} 2$ in polyamine analogue-treated human breast cancer cell lines. J Biol Chem 280: $39843-39851$

Schwarzer R, Dames S, Tondera D, Klippel A, Kaufmann J (2006) TRB3 is a PI 3-kinase dependent indicator for nutrient starvation. Cell Signal 18: $899-909$

Seher TC, Leptin M (2000) Tribbles, a cell-cycle brake that coordinates proliferation and morphogenesis during Drosophila gastrulation. Curr Biol 10: 623-629

Shor B, Zhang WG, Toral-Barza L, Lucas J, Abraham RT, Gibbons JJ, Yu K (2008) A new pharmacologic action of CCI-779 involves FKBP12independent inhibition of mTOR kinase activity and profound repression of global protein synthesis. Cancer Res 68: 2934-2943

Sobin LH, Fleming ID (1997) TNM Classification of Malignant Tumors, fifth edition (1997). Union Internationale Contre le Cancer and the American Joint Committee on Cancer. Cancer 80: 1803-1804

Sung HY, Guan H, Czibula A, King AR, Eder K, Heath E, Suvarna SK, Dower SK, Wilson AG, Francis SE, Crossman DC, Kiss-Toth E (2007) Human tribbles-1 controls proliferation and chemotaxis of smooth muscle cells via MAPK signaling pathways. J Biol Chem 282: $18379-18387$

Wang H, Davis A, Yu S, Ahmed K (2001) Response of cancer cells to molecular interruption of the CK2 signal. Mol Cell Biochem 227: 167-174

Weeks JC, Nelson H, Gelber S, Sargent D, Schroeder G (2002) Short-term quality-of-life outcomes following laparoscopic-assisted colectomy vs open colectomy for colon cancer: a randomized trial. JAMA 287: $321-328$

Wolpin BM, Mayer RJ (2008) Systemic treatment of colorectal cancer. Gastroenterology 134: 1296-1310

Wu CW, Kao HL, Li AF, Chi CW, Lin WC (2006) Protein tyrosinephosphatase expression profiling in gastric cancer tissues. Cancer Lett 242: $95-103$

Xu J, Lv S, Qin Y, Shu F, Xu Y, Chen J, Xu BE, Sun X, Wu J (2007) TRB3 interacts with CtIP and is overexpressed in certain cancers. Biochim Biophys Acta 1770: 273-278

Yamasaki M, Takemasa I, Komori T, Watanabe S, Sekimoto M, Doki Y, Matsubara K, Monden M (2007) The gene expression profile represents the molecular nature of liver metastasis in colorectal cancer. Int J Oncol 30: $129-138$

Yamatodani T, Ekblad L, Kjellen E, Johnsson A, Mineta H, Wennerberg J (2009) Epidermal growth factor receptor status and persistent activation of Akt and p44/42 MAPK pathways correlate with the effect of cetuximab in head and neck and colon cancer cell lines. J Cancer Res Clin Oncol 135(3): $395-402$

Yao XH, Nyomba BL (2008) Hepatic insulin resistance induced by prenatal alcohol exposure is associated with reduced PTEN and TRB3 acetylation in adult rat offspring. Am J Physiol Regul Integr Comp Physiol 294: R1797-R1806

Yde CW, Frogne T, Lykkesfeldt AE, Fichtner I, Issinger OG, Stenvang J (2007) Induction of cell death in antiestrogen resistant human breast cancer cells by the protein kinase CK2 inhibitor DMAT. Cancer Lett 256: $229-237$

Zheng X, Resnick RJ, Shalloway D (2008) Apoptosis of estrogen-receptor negative breast cancer and colon cancer cell lines by PTP alpha and src RNAi. Int J Cancer 122: 1999-2007 